\title{
The Strong U.S. Dollar: A Dilemma for Foreign Monetary Authorities
}

\author{
DALLAS S. BATTEN and JAMES E. KAMPHOEFNER
}

OLSTERED by higher short-term market interest rates and a lower rate of inflation than those abroad, the U.S. dollar has been quite strong in foreign exchange markets since the middle of 1980 . Its tradeweighted value has risen 35 percent from July 1980 to April 1982. The general strength of the dollar has elicited sharp criticism from foreign monetary authorities who argue that a stronger dollar forces them to choose between two unpleasant alternatives: follow domestic policies that result in historically high interest rates or accept depreciation of their currencies.

Within the standard conceptual framework of exchange rate determination, movements of exchange rates, in the short run, are caused primarily by changes in interest-rate differentials. ${ }^{2}$ Specifically, an increase in U.S, interest rates relative to those abroad should result in an increase in the foreign currency value of the dollar, other things equal. As the above criticisms demonstrate, however, exchange rate movements also may play an important role in influencing monetary

\footnotetext{
The trade-weighted exchange rate is an average of the value of the dollar against 10 other currencies weighted by each country's trade share. The conntries ineluded are Belgiun, Canada, Ftance, Germany, Italy, lapan, the Netherlands, Sweden, Switzerland and the United Kingdon. For a more detailed explanation, see "Index of the Weighted-Average Exchange Valte of the U.S. Dollar: Revision," Federal Reserve Bulletin (Angust 1976), p. 700. The trade weighted foreign interest rate presented below is a weighted average of short-term market interest rates for the same countries using the same weights.

To be technically correct, short-run exchange rate movements are motivated by differences il real in terest rates, 1.6 , market interest rates adjested for expected inflation. For a more thorough discussion, see Dallas S. Batten, "Foreign Exchange Markets: The Dollax in 1980," this Review (April 1981), pp. 22-30. Consequently, changes in market interestrate differentials and movenents of exhange rates should be positively related only if the changes in market interest-rate differentials reflect changes in ral interestrate differentials.
}

policy actions in some countries, which will be reflected in turn by changes in their short-term domestic interest rates. That is, a foreign monetary authority's response to changes in the exchange value of its currency may be to pursue a policy that affects the levels of its domestic interest rates. Consequently, when observing movements of both the exchange rate and the interest-rate differential, it is not immediately clear whether a change in the differential causes the exchange rate to change or whether the interest rate change is a monetary policy response to the exchange rate movement.

This element of uncertainty has been especially prevalent for the first three quarters of 1981. Chart 1 presents the trade-weighted foreign currency value of the dollar and the difference between the U.S. threemonth $C D$ rate and the trade-weighted foreign interest rate. While these two series exhibit the expected positive relationship before the first quarter of 1981 and after the third quarter of 1981, they display no statistically significant relationship during the first three quarters of $19811^{3}$

On the other hand, chart 2 contains the tradeweighted foreign currency value of the dollar and the trade-weighted foreign interest rate. The relationship between these two series shows a much different pattern than that between the dollar and the interest-rate differential. While demonstrating only a weak positive relationship before 1981, the trade-weighted value of the dollar and the trade-weighted foreign interest rate

\footnotetext{
The calculated correlation coefficients between the trade-weighted dollar exchange rate and the interest-rate differential reported weekly for the approximate periots, 1/1980-WV/1980, J/1981-III/ 1981 and IV/1981-II/1982, are $.795, .158$ and .828 , respectively. The corresponding critical values at the 5 percent level are .266 , .320 and 339 , respectively.
} 


\section{Chant \\ Foreign Exchange Value of the Dollar and U.S.-Foreign Interest Rate Differential}



follow extremely similar paths during the first three quarters of 1981. Beginning in the last quarter of 1981 , however, their paths diverge radically, with the tradeweighted foreign interest rate in April 1982 falling to its July 1980 level, while the dollar continues to rise in general. ${ }^{4}$ Foreign monetary authorities apparently have been relatively more responsive to exchange rate movements (especially of the dollar) during most of 1981 than previously. Moreover, it also appears that foreign monetary authorities recently have changed their response to an increasingly strong dollar.

The purpose of this article is to examine this recent experience using an analytical framework that describes and evaluates the policy altematives available to a foreign monetary athority whose currency is depreciating. Of particular importance are the relationship between external and internal policy objec-

\footnotetext{
The calculated correlation coefficien between the trade-weighted dollar exchange rate and the trade-weighted foreign interest rate for the periods listed in footnote 3 are $.379, .899$ ant -.789 , respectively. The critical values are the same as those in footnote?
}

tives, the role played by exchange rate movements in the formation of domestic monetary policy and the conseguences of the policy choice.

\section{POP}

Since the difference between U.S, and foreign short-term interest rates is a primary determinant of short-run exchange rate movements, a monetary anthority has essentially three policy choices when domestic interest rates adjusted for relative inflation rates) are below those of another country. First, it can do nothing and allow its exchange rate to depreciate sufficiently to compensate for the interest differential. In this case the economy will incur increased domestic unemployment in the short run as donestic resources are reallocated from the production of nontradable goods to the production of tradable goods in response to changing relative prices. If the exchange rate movement is expected to be only temporary, however, this reallocation may be undesirable since relative prices are expected to return to previous levels. Furthermore, it is possible that domestic prices 


\section{Chart 2 \\ Foreign Exchange Value of the Dollar and the Foreign Interest Rate}

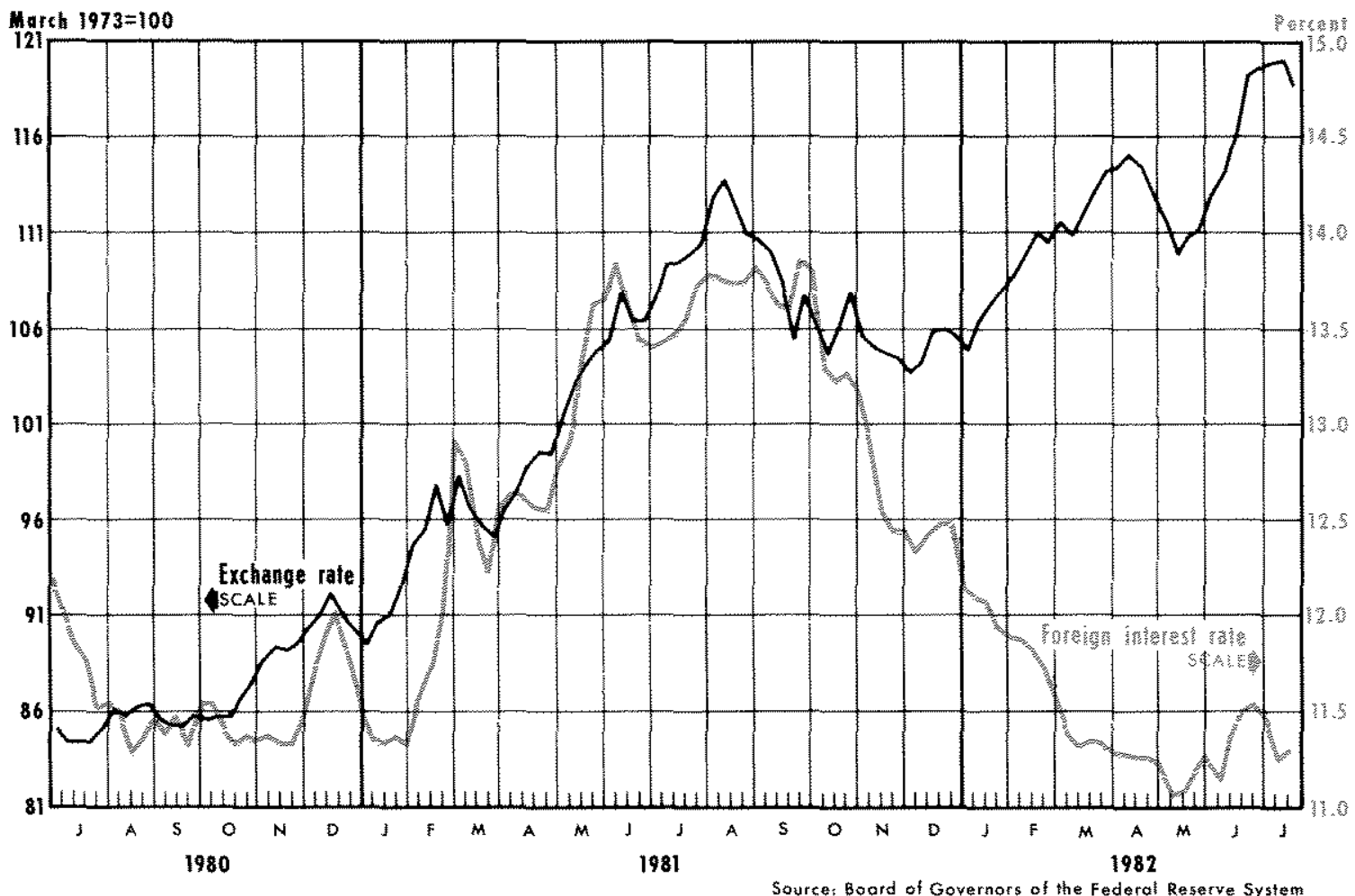

may rise with the prices of imports as domestic demand shifts to import-competing products. ${ }^{5}$

Second, it can adopt a tighter monetary policy to raise short-term domestic interest rates, thereby reducing the interest-rate differential and mitigating the downward pressure on its exchange rate. ${ }^{5}$ If this tighter stance conflicts with the country's domestic objectives, the short-run costs of this choice are increased domestic unemployment and lower real output growth.

Third, a monetary authority can intervene in foreign currency markets by purchasing its own currency with its reserves of foreign currency. This would increase the demand for domestic currency relative to foreign currency and produce, at least temporarily, a reduc-

\footnotetext{
"Ste R. I. MoKinnon, "Optimum Currency Areas," American Economic Rexiew (September 1965), pp. 717-24.

The monetary athorites of nost of the industria countries other than the United States employ interest rate targeting as a means of controlling their money supplies. Consequently, a desire to lower the rate of money growth will lead to an increase in market in terest ates (at least in the short run). Casual observation of the relatonship between short-term market interest rates and the rate of money growth in these countries supports this conclusion.
}

tion in the downward pressure on its exchange rate. It is not immediately clear whether the intervention will affect the exchange rate permanently. Consequently, an investigation of the conditions under which $\mathrm{m}$ tervention will permanently affect the long-run path of exchange rate movements is crucial in determining whether intervention can be effective in counteracting the impact of unfavorable interest-rate differentials on the exchange rate. ${ }^{7}$

In analyzing the permanent nature of the impact of central bank intervention on the exchange rate, one must distinguish sales or purchases of foreign currencies that affect the size of the domestic money supply

\footnotetext{
Intervention policy nay not be necessarily aimed at permanently affecting the exchange rate. Instead its focus may be simply to smooth short-run exchange rate fluctuations without having any impact on the long-run path of exchange rate movenents. In this later case, intervention that only temporarily affects exchange rates is sufficient to accomplish this objective. See, for example. Michael Mussa, "The hole of Official Intervention," Occasional Paper No. 6 (Croup of Thirty, 1981). The purpose of this article. however, is to analyze policy alematives designed to counteract the impact of unfavorable nnterest rate differentials. Consequent1) the presumed goal of smoothing short-run exchange riste fuctuations is ignored leere.
} 
from those that do not. ${ }^{8}$ Specifically, intervention is said to be "sterilized" if its impact on the domestic money supply is offset by the sale or purchase of domestic assets by the central bank. Intervention is said to be "unsterilized" if its effect on the level of commercial bank reserves and, consequently, the domestic money supply is not offset (see box).

\section{Wnoterihted horvenion and



Suppose, for example, that the Fed attempts to prevent the dollar from depreciating by purchasing dollars with Deutsche marks (DM). If this intervention is unsterilized, it can affect the exchange rate in at least three ways. First, because the Fed's purchase of dollars temporarily increases the flow demand for dollars relative to the supply of dollars, the immediate effect should be an appreciation of the dollar (or a depreciation of the Deutsche mark $)^{9}$ This result, however, will be only transitory unless the Fed continues to purchase dollars day after day, thereby maintaining the higher flow demand for dollars. ${ }^{10}$

Second, since this transaction is unsterilized, it causes the U.S. money supply to fall and the German money supply to rise. All other things equal, there will be an excess demand for U.S. money in the United States and an excess supply of German money in West Germany - a stock disequilibrium that can be rectified only if aggregate spending falls in the United States and rises in Germany. This decline in U.S. spending and rise in German spending will cause the general price level in the U.S. to fall and that in Ger-

\footnotetext{
${ }^{3}$ For convenience, it is assumed that all intervention operations are performed by the central bank. See A. B. Babach. "The Mechanics of Intervention in Exhange Markets," this Review February 1978 p p. 2-7, for a discussion of various other types of intervention operations.

9f the parpose of the intervention activity is to "lean against the wind, "its impact may be insufficient to offset completely the effect of changes in fundanental deteminants of the movement of the exchange rate. Conseguently, intervention activity may not completely reverse the direction of exchange rate movenemts, but only slow the rate of change.

${ }^{10}$ All other things equal, if the increased flow demand is not maintained, demand and supply conditions in foreign currency markets will return to what they were proor to the Fed's intervention activity. Hence, this impact would only be temporary. See Michael Mussa, "Empirical Regularities in the Behatior of $\mathrm{Ex}$ change Rates and Theories of the Foreign Exchange Market, in Karl Brumer and Allm H. Meltzer, eds. Policies for Employment, Prices and Exchange Rates. Camegie-Rochester Conference Series on Public Policy, supplement to the Journal of Monetary Economics, Volune 11 (1979), pp. 9-57, especially pp. 27.38 .
}

many to rise and, at the same time, motivate a pernanent appreciation of the dollar. ${ }^{11}$

Finally, market participants may interpret the decrease in the U.S. money stock as an indication of further tightening of monetary policy by the Fed in the future. Since an exchange rate is the relative price of two specific financial assets the two domestic monies involved), it is crucially influenced by expectations about the course of future events. Consequently, expectations of a tighter U.S. monetary policy in the future should place additional upward pressure on the current $\mathrm{DM} /$ dollar exchange rate as market participants anticipate the lower U.S. and higher German price levels described above. ${ }^{12}$

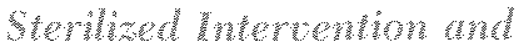 Exhmge Wate Wownows}

The immediate impact of sterilized intervention is the same as that for unsterilized intervention; that is, it creates a transitory increase in the flow demand for dollars, causing a temporary appreciation of the DM/ dollar exchange rate. The net effect of sterilized intervention, however, is simply a purchase of domestic securities with foreign securities. Consequently, neither country's money supply will be affected; instead, private portfolios will contain fewer dollardenominated and more DM-denominated securities.

Inasmuch as sterilized intervention affects neither the monetary factors that influence the long-run behavior of prices nor the real factors that determine the relative competitiveness of the economies, it is unclear initially what lasting impact it has on the DM/dollar exchange rate. It can have a permanent impact on the exchange rate if the public views domestic and foreign securities as being imperfect substitutes for each other. ${ }^{1 / 3}$ Because these securities are denominated in different currencies, it is argued, the impact of exchange-rate movements and the possibility of ex-

\footnotetext{
"See, for example, Batten, "Foreign Exchange Markets."

${ }^{12}$ See Jacob A. Frenkel, "Flexble Exchange Rates, Prices, and the Role of "News": Lessons from the 1970s," Journal of Political Economy (August 1981). pp. 665-705

${ }^{13}$ See Dale W. Henderson, "Modeling the Interdependence of National Money and Capital Markets." American Economic Reciet (February 1977), pp. 190 99; Lance Girton and Dale Hendersol, "Gentral Banks Operations in Foreign and Domestic Assets Under Fixed and Flexible Exchange Rates." in Peter 13. Clark, Dennis E. Loove, and Richard I. Sweeney, eds. The Effects of Exchange Rote Adjustments Government Printing Office 1976) po $151-79$. Peter Isard, Exhange-Rate Determinafion: A Survey of Popular Vieus and Recent Models, Princeton Studies in Intenational Finane No, 42 (Princeton University Press, 1978 .
} 


\section{The Mechanics of Foreign Exchange Market Intervention}

Suppose that the Federal Reserve purchases dollars: (in other words, sells foreign currency - nost often Deutsche marks) in foreign exchange markets in an attempt to prevent (or slow) the dollar from depreciating. To do this, the Fed must have some Deutsche marks, which it typically acquires either by selling some of its non-negotiable DM-denominated securities to the Bundesbank or by borrowing DM from the Bundesbank in exelange for a DM. denominated account Since both of these transactions are between central banks only, they have no impact on the size of either country s money stock.

The Fed then buys dollar-denominated demand deposits of foreign commercial banks held at U S commercial banks and pays for then from its DM deposits at the Bundesbank. This produces an inerease in foreign commercal banks' reserve accounts at the Bundesbank and a decrease in their denand deposits held at U S commercial banks. On the other hand, for U.S commercial banks, bot their reserve accounts at the Fed and their demand deposit liabilities to foreign commercial banks have deelined sincel U.S conmercral banks reserves haye fallen while German conmercial banks reserves have risen, the U. 5 . money stock will decrease and West Germany s noney supply will increase as a result of this foreign exchange market operation:

As this example of unsterilized intervention shows,

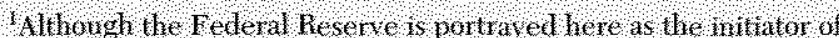
exehange narket intervention the and sis would not difter segif
} reantly in the tase of intenchtion by foreign anthontes.

change or capital controls adds an element of risk to the holding of foreign assets that cannot be totally eliminated with a diversified portfolio, ${ }^{14}$

If dollar-denominated and DM-denominated securities were perfect substitutes, no change in the exchange rate or in interest rates would be required to motivate investors to hold the new portfolio that contains fewer dollar-denominated and more DMdenominated securities. If, however, these securities are not perfect substitutes, investors will be unwilling to hold the new portfolio and, at the original exchange rate and interest rates, an excess demand for dollar-

"See Girton and Henderson, "Central Bank Operations," pp. 15253. the U.S money supply has not been insulated from the foreignexchange market transaction. If however, central banks do not want their foreign exchange intervention to affect their domestic money supply, they may sterilize its impact with an offsetting sale or purchase of domestic assets. Continuing the previous example, if the Fed does not want U.S commereal banks to lose reserves as a result of its foreign exchange intervention to support the dollar, it can purchase U S. government securities equal to the amount of the reserves that banks lose, thereby maintaining the level of reserve accounts of the US, commercial banks. In this manner, the negative impact of intervention on the reserves of $U \mathrm{~S}$ commercial banks is exactly offset with no subsequent change in the 1 S, money stoek.

In a smilar fashon, the Bundeshank could neutral ize the inpact of the US intervention on the Cerman money supply by draining the newly created reserves from the West German commercial banking system. 2 if completely sterilized the foretgn exchange opera tion affects neither country s money supply. Private portfolios contain fewer dollar-denominated securities and more DM denominated seemrities, while the Fed portfolio contains nore dollar denominated and fewer DM-denominated securities:

\footnotetext{
The institutional aramgentents for acconplishng thes wat differ across De contutres, the entot neans used are not important here

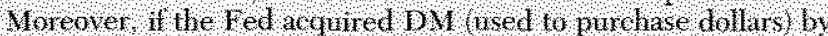

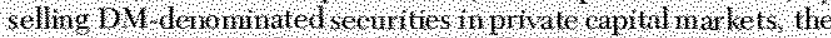
German noney suppl, would not be alle eled by the nntersention actwity and the Bandesbank wodld not have to sterilize the opera tion.
}

denominated securities (and an excess supply of DMdenominated securities) will exist. Consequently, investors will attempt to acquire additional dollardenominated securities and sell DM-denominated securities in order to return their portfolios to the desired proportion of dollar-denominated to DMdenominated securities, placing upward pressure on the DM value of the dollar. ${ }^{15}$ In other words, even though the two domestic money supplies have been unaffected by the intervention activity, the resulting portfolio disequilibrium (caused by foreign and domestic securities being imperfect substitutes) has a permanent impact on the exchange rate.

\footnotetext{
"The realignment of portfolios will, at the same time, place upward pressure on Geman interest rates and downward pressme on U.S. interest rates.
} 
Since the efficacy of sterilized intervention hinges on the imperfect substitutability of foreign and domestic securities, the degree of substitutability that actually exists is crucial. Empirical tests of the existence of this risk have yielded mixed results. ${ }^{16}$ Thus, whether sterilized intervention has a significant lasting impact on exchange rates remains uncertain.

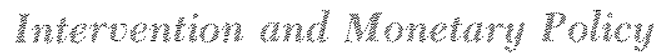

It seems that if the monetary authority wants to influence permanently the path of its exchange rate, and not merely dampen short-rum fluctuations, it must engage in unsterilized intervention. It is clear, however, that unsterilized intervention is tantamount to con ${ }^{-}$ ducting monetary policy through foreign exchange market operations. Hence, in this case, intervention is not really an alternative to monetary policy but merely a variant of it. Only sterilized intervention is a distinct policy alternative.

Since there can be only a single monetary policy stance, the role of unsterilized intervention depends critically on the importance that policymakers place on the exchange rate in relation to other economic variables, as a factor influencing the conduct of monetary policy. In particular, the use of unsterilized intervention (with the concomitant impact on the domestic money supply) implies that the monetary authority places relatively more importance on reducing the risks and the real economic disturbances associated with exchange rate movements than on influencing domestic prices, output and employment.

Since the exchange rate is the relative price of two domestic monies, it is affected, among other things, by changes in the demand for foreign money, actual and expected policy changes of foreign monetary authorities, and whatever changes emanate from within the

\footnotetext{
${ }^{16}$ Jeffrey A. Frankel. "A Test of the Existence of the Risk Premium in the Foreign Exchange Market vs. the Hypothesis of Perfect Substitutability" International Finance Discussion Paper No. 119 (Board of Governors of the Federal Reserve System, August 1979) finds no support at all for the existence of a risk premium. Alternatively, Richard Meese and Kenneth I. Singleton, "Rational Expectations, Risk Premia, and the Market for Spot and Forward Exchange." International Finance Discussion Paper No. 165 Board of Governors of the Federal Reserve System, July 1980) concludes that the failure of the forward exchange rate to be an unbiased predictor of the future spot rate is a conseguence of the existerce of a risk premium. Finally, Maurice Obstreld, "Can We Sterilize? Theory and Evidence" NBER Working Paper No. 833 (January 1.982) finds evidence of imperfect asset substitutability, but questions the ability of central banks to exploit it. "That is, imperfect asset substitutability appears to be a necessary, but may not be a sufficient, condition for sterilized in tervention to have significant impact on the exchange rate.
}

domestic economy itself. Directing domestic monetary policy at an exchange rate target, therefore, subjects the economy to both domestic and foreign infuences. Consequently, the monetary authority loses its ability to control its own money supply independently of foreign actions and events. ${ }^{17}$

The desire to influence the movement of exchange rates without losing control of the money supply is the primary rationale for using sterilized intervention. As discussed above, however, it is not clear that sterilized intervention has a significant lasting impact on exchange rates. Sterilized intervention may be an appropriate policy to reduce unwanted short-run variability of exchange rates for which there may be no readily identifiable cause. When monetary anthorities desire to alter the path of exchange rate movements, however, sterilized intervention may be inadequate. Consequently, monetary policymakers must choose between internal and external objectives. ${ }^{18}$

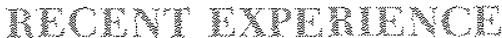

Monetary authorities seldom choose the first policy alternative discussed above; they don't appear to like to "do nothing" about the problems that they face. Studies of central banks' demand for and use of foreign currencies, as well as reports from central banks themselves, indicate that large-scale intervention in foreign currency markets has continued since the movement to floating exchange rates in 1973 . $^{19}$ If central bankers desire to influence exchange rates, the policy choice narrows down to sterilized or unsterilized intervention. Although policymakers might prefer sterilized intervention, since it appears to allow them to separate

\footnotetext{
"The extreme case is the one in which the monetary anthority desires to mantain a completely fixed exchange rate. In this case, the monetary authority has no ability at all to infuence the size of its domestic money supply. See Herbert G. Grubel, International Economies (Richard D. Irwin, Ine, 1977), pp. 375-80.

${ }^{8}$ For an example of a monetary anthority's recognition of this dilenwa, see Monthly Report of the Deutsche Bundesbank (f ebrtary 1981), p. 7.

${ }^{9}$ See, for example, Dallas S. Batten, "Central Banks" Denand for Foreign heserves Under Fixed and Floating Exchange Rates," this Retiew (March 1982), pp. 20-30; Jacob Frenkel, "The Demand for Latemational Reserves Under Pegged and plexible Fxchange Rate Regimes and Aspects of the Managed Flont," in David Bigman and Teizo Taya, eds. The Functioning of Floating Exchange Rates Ballinger, 1980), pp. 161-95; H. Robert Helle: and Mohsin S. Kahn, "The Demand for International Reserves Under Fixed and Floating Exchange Rates," IMF Staff Papers (December 1978), pp. 62349; and john Williamson, "Exchange Rate Flexibility and Reserve Vse," Scandinatian Journal of Economics (No. 2, 1976), pp. 327-39.
} 
Table 1

Quarterly Money Growth for Selected Countries (compounded annual rates, seasonally adjusted)

\begin{tabular}{|c|c|c|c|c|c|c|c|}
\hline County & 11180 & Noro & $1 / 81$ & 181 & 1181 & $1 / 81$ & 182 \\
\hline Canada & $132 \%$ & $163 \%$ & $11 \%$ & $47 \%$ & $38 \%$ & $160 \%$ & $148 \%$ \\
\hline France & 83 & 102 & 113 & 132 & 108 & 188 & $\mathrm{NA}$ \\
\hline Gemany & 45 & 95 & 18 & 48 & 116 & 05 & 56 \\
\hline taly & 118 & 162 & 168 & 45 & 30 & 10,1 & 155 \\
\hline dapan & 81 & 35 & 26 & 210 & 33 & 110 & 87 \\
\hline Netherlands & 67 & 10.2 & 49 & 53 & 49 & 57 & 135 \\
\hline Switeriand & 55 & 48 & 10.4 & 28 & 35 & 147 & 415 \\
\hline Uniled Kingoom & 120 & 131 & 158 & 145 & 51 & 14 & 101 \\
\hline
\end{tabular}

source Federal Beserve bank of St Louls, hentional Economic Condtions:

exchange rate policy from domestic monetary policy, they have come to realize that sterilized intervention will not suffice, at least in some situations. The last year and a half provides a good example of the trade-off inherent in the choice of intervention policy.

From the middle to the end of 1980 , the foreign currency value of the dollar rose along with U.S.foreign short-term interest differentials. During this period (actually, since about November 1978), the U.S. monetary authority had intervened frequently and on a consistently large scale in foreign currency markets; it primarily "leaned against the wind," that is, bought dollars when the dollar was depreciating and sold dollars when it was appreciating.

With the advent of the Reagan administration, the Treasury announced that it (along with the Federal Reserve) would cease daily intervention except for periods of substantial exchange market volatility. This removed an extremely large and cooperative participant from foreign currency markets. Consequently, foreign monetary authorities who desired to remain active in foreign currency markets were faced with two policy options if they wished to have the same impact on exchange rates as before: either increase the amount of their intervention (if they wished to continue to sterilize it) or sterilize less of their existing intervention.

The magnitude of foreign central bank intervention activity has not changed significantly since the change in U.S. intervention policy. There is evidence, howev$e r$, of more unsterilized intervention since this change. Table 1 contains the quarterly rates of M1 growth for several major industrial countries that are important trading partners of the United States. Except in France and Japan, MI growth in each country displays a sig. nificant slowing during $1981 .{ }^{20}$ The abruptness of this change can be seen more clearly in table 2 , which reports three-month money growth rates for five of these countries. Not surprisingly, foreign short-term market interest rates also began to rise rather dramatically in early 1981 . In fact, as shown in chart 2 , market interest rates of the major trading partners of the United States generally moved with the tradeweighted exchange rate during the first three quarters of 1981, apparently because foreign monetary authorities were tightening their monetary policies in attempts to mitigate the rise of the U.S. dollar. ${ }^{21}$

\footnotetext{
${ }^{30}$ Ever though Canada the only cotutry considered that explicitly targets on the Ml defnition of money, this definition is employed because it has been found to be an appropriate indicator of mone. tary policy. See Dallas S. Batten, "Money Growth Stability and Inflation: An Intemational Comparison, " this Review (October 1981), pp. 7-12; and Dallas S. Batten and R. W. Hafer, "ShortRun Money Crowth Fluctuations and Real Economic Activity: Some Implications for Monetary Targeting," this Review (Nay 1981), pp. 15-20. For France, however, M] growth may be a poor indicator of the stance of monetary policy after Mitterand took office in mid-1981. The new administration imposed severe interest rate ceilings on savings and time deposits, whicli motivated relatively large fows from acounts not included in $\mathrm{Ml}$ to accounts induded in $M 1$. The net resalt was extremely rapid M 1 growth.

${ }^{21}$ The relationship between the trade-weighted value of the U.S. dollar and the trade-weighted foreign interest rates (shown in chart 2) is much closer in the first three quarters of 1981 than in any interal since the beginning of the United States prointervention stance. Obviously, all monetary policy actions taken by these countries do not necessarily reflect the desire to achieve exchange rate objectives. For example, Germany has experienced a large current account deficit and Canada and Switzerland kave each encountered accelerating domestic inflation. The magnitude of the change in money growth at the beginning of 1981 and the fact that the timing of the response so closely paralleled the change in U.S. policy, however, certainly provide a castal verification that exchange rate objectives have played an important role.
} 
Table 2

Three-Month Money Growth for Selected Countries (compounded annual rates, seasonally adjusted)

\begin{tabular}{|c|c|c|c|c|c|c|}
\hline & bate & Canada & Germany & taly & Netherlands & Switzelland \\
\hline \multirow[t]{3}{*}{1980} & October & $183 \%$ & $96 \%$ & $102 \%$ & $119 \%$ & $74 \%$ \\
\hline & November & 222 & 166 & 134 & 82 & 47 \\
\hline & December & 09 & 25 & 245 & 104 & 24 \\
\hline \multirow[t]{12}{*}{1981} & January & 19 & 70 & 207 & 99 & 63 \\
\hline & Bebruary & 43 & 38 & 177 & 65 & 77 \\
\hline & March & 62 & 21 & 117 & $\$ 17$ & 16.8 \\
\hline & Apri & 11 & 115 & 57 & 28 & 16 \\
\hline & May & 82 & 8.2 & 37 & 48 & 27 \\
\hline & June & 46 & 60 & 65 & 82 & 41 \\
\hline & ouls? & 67 & 29 & 52 & 107 & 29 \\
\hline & August & 70 & 34 & 22 & $\$ 50$ & 57 \\
\hline & September & 106 & 66 & 09 & 14 & 68 \\
\hline & October & 328 & 41 & 38 & 88 & 111 \\
\hline & Novembet & 198 & 08 & 66 & 98 & -140 \\
\hline & December & 227 & 51 & 219 & $1+1$ & 996 \\
\hline \multirow[t]{3}{*}{1982} & Jancan & 326 & 99 & 247 & 8.6 & 882 \\
\hline & Feoruary & 280 & 22 & 214 & 29 & 940 \\
\hline & March & 0.5 & 49 & 21 & 287 & 177 \\
\hline
\end{tabular}

SOURCES. Bank of Canada Revew, Monthly Aeport of the Deutsche Bundesbank, Board of Gov emors of the Federal Resene System, and Intenational Monetary Fund, Intemational Finaffial Statis tcs Germany and ltaly seasonally adjusted by this Bank.

These policy decisions to limit the rise in the exchange value of the dollar, however, were not costfree, as charts 3 and 4 show. Continued economic stagnation was the price paid for redirecting monetary policy. Except for Japan, all countries experienced rising unemployment and little or no real economic growth during the first three quarters of 1981.

In light of the economic conditions at the time, it is not too surprising that foreign central banks responded differently to a rising U,S. dollar at the end of 1981 and the beginning of 1982 than they did at the beginning of 1981. In particular, the re-emergence of a strong dollar at the end of 1981 did not elicit a tighter monetary policy stance and the subsequent higher short-term interest rates that had occurred at the beginning of the year. ${ }^{22}$ Since, in general, these countries have continued to experience economic stagnation, it appears

\footnotetext{
${ }^{22}$ The increase in the rates of money growth abroad at the beginning of the fourth quarter of 1981 most likely contributed to the subseanent rise in the foreign currency value of the dollar. The point made, however, is that once a relatively strong dolar re-emerged, foreign monetary authorities did not appear to respond in the same manner as they had at the beginning of 1981
}

that central banks were unwilling to exacerbate the situation by subjecting their economies to even tighter monetary conditions necessary to raise domestic interest rates further and moderate the rise of the dollar. In fact, foreign short-term interest rates fell considerably during the last quarter of 1981 and the first quarter of 1982. Thus, foreign central banks now seem willing to allow the foreign exchange value of their currencies to depreciate instead.

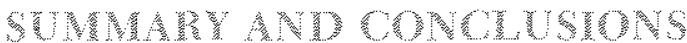

This article has attempted to describe, using a simple anatytical framework, both the policy alternatives available to a central bank and their consequences. During the floating exchange rate period, central banks consistently have intervened in foreign currency markets. Because unsterilized intervention dimmishes a central bank's ability to control its domestic money stock, it generally has opted to separate external and internal policy objectives by sterilizing the impact of intervention on its money stock. Sterilization, however, decreases the efficacy of intervention. Consequently, foreign central banks welcomed the U.S." pro- 
Charl 3

\section{Growth of Real Output}

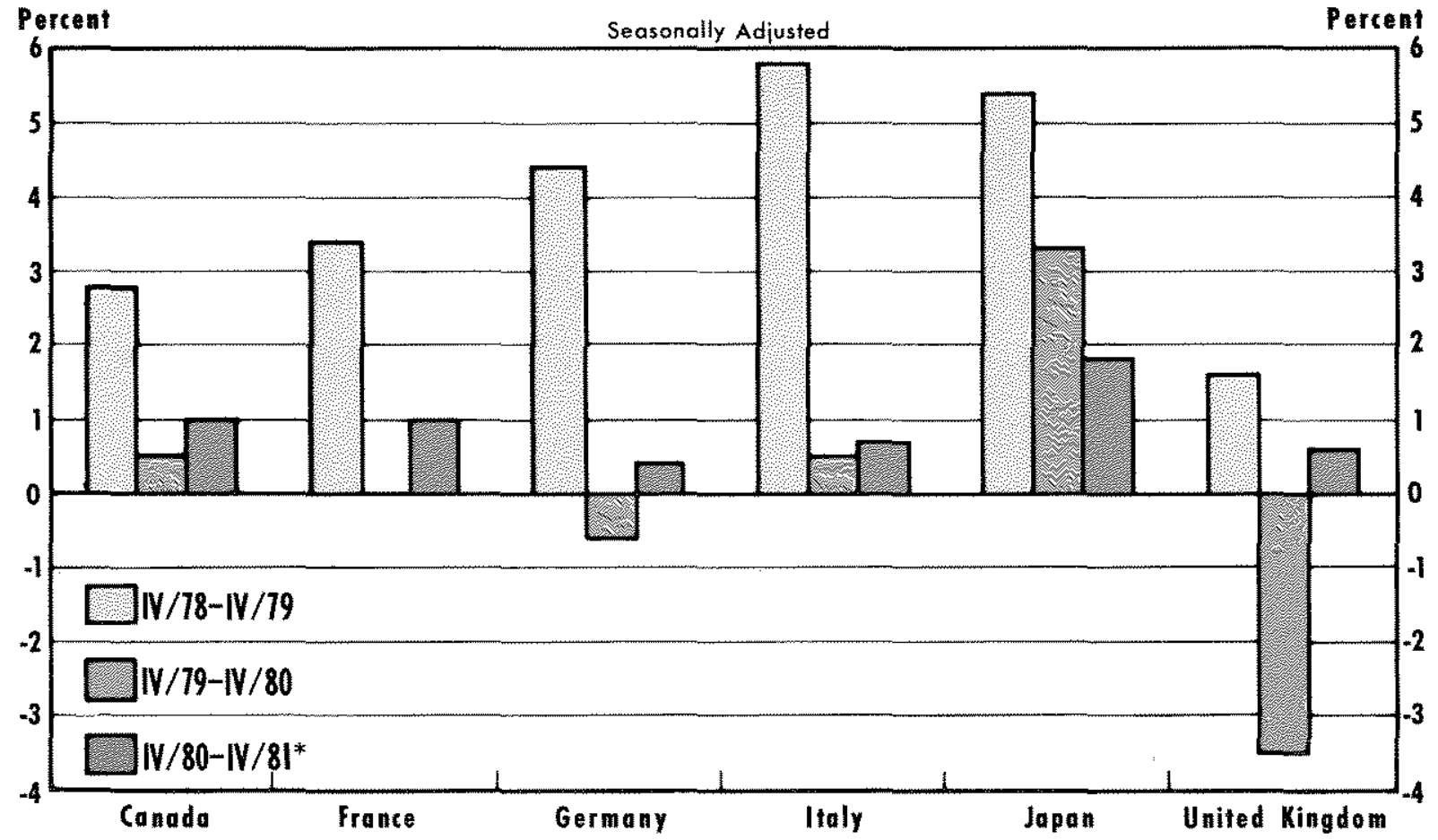

Source: Federal Reserve Bank of St. Lovis, International tconomic Conditions.

*For France, the dato available is for $11 / 181$.

J

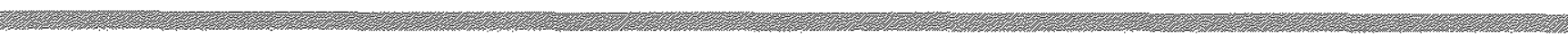

Chart A

Unemployment Rate

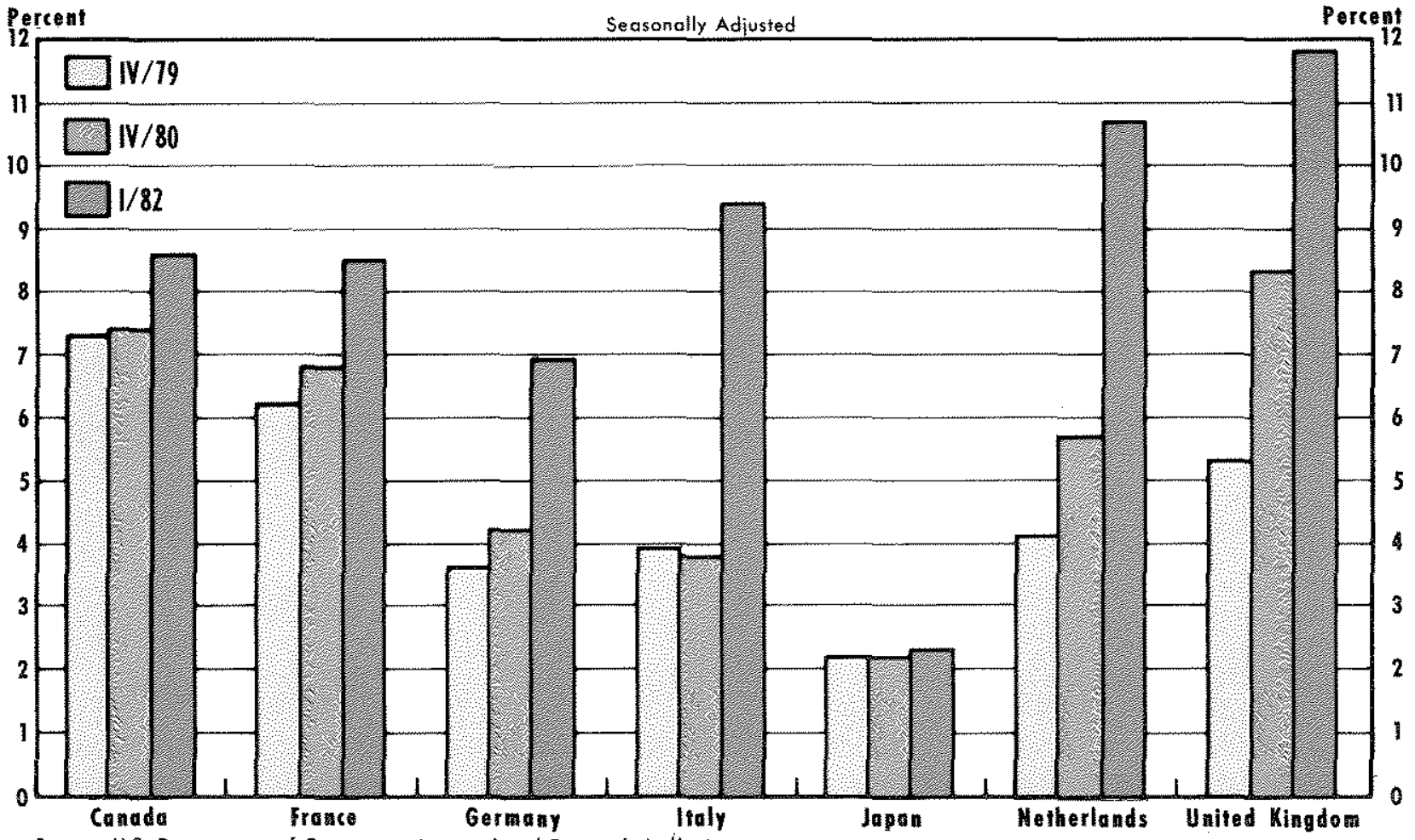

Soutce: U.S. Department of Commerce, Internotional Economic indicators. 
intervention stance initiated in late 1978 and were disappointed with the Reagan administration's decision to abandon this position in February 1981.

The evidence presented in this article suggests that the February 1981 pollcy change has forced foreign central banks that wish to influence exchange rate movements to ater their domestic monetary growth rates. In particular, since the exchange value of the U.S. dollar generally has been rising during the past two years, foreign central banks have had to choose between allowing their currencies to depreciate and changing their monetary grow thates drastically. They chose the latter in early 1981 . Money growth slowed dramatically, resulting in continued domestic economic stagnation in many of the countries examined. Since the end of 1981 , they have opted for the former policy choice and, as a result, the foreign exchange value of the dollar has increased substantally while money growth in the various countries has eased.

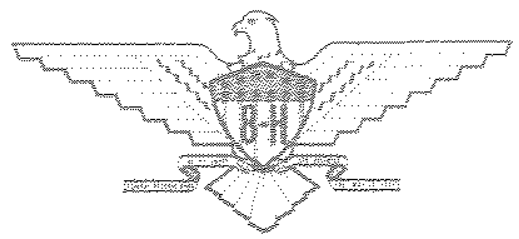

